\title{
"Sibaaqun" Edukasi Pengenalan Huruf Hijaiyah Melalui Media Permainan Papan
}

\author{
${ }^{1}$ Moch. Tryandi Budiman Sasmita, ${ }^{2}$ Samuel Gandang Gunanto, \\ ${ }^{3}$ Pandan Pareanom Purwachandra \\ ${ }^{1}$ Program Studi Animasi, Fakultas Seni Media Rekam, Institut Seni Indonesia Yogyakarta \\ mochtryandibs@gmail.com \\ ${ }^{2}$ Program Studi Animasi, Fakultas Seni Media Rekam, Institut Seni Indonesia Yogyakarta \\ gandang@isi.ac.id \\ ${ }^{3}$ Program Studi Animasi, Fakultas Seni Media Rekam, Institut Seni Indonesia Yogyakarta \\ pianisganteng@yahoo.com
}

\begin{abstract}
Abstrak
Dunia anak sangat identik dengan permainan atau bermain. Anak-anak melakukan belajar dengan bermain atau dengan melakukan sebuah permainan. Namun seiring berkembangnya zaman, banyak permainan-permainan yang lebih banyak memberikan dampak negatif terhadap anak-anak. Penciptaan karya dengan judul "Sibaaqun Media Edukasi Pengenalan Huruf Hijaiyah dan Syiar Islam melalui Board Game", memiliki tujuan menyampaikan pengetahuan Agama Islam dan mengenalkan huruf-huruf Hijaiyah kepada anak-anak melalui media permainan papan. Penciptaan karya board game ini bermaksud untuk mengurangi dampak negatif yang diterima anak-anak ketika bermain. Dengan cara mebuat sebuah permainan dengan menyisipkan edukasi di dalamnya, dan juga membuat bagaimana supaya permainan berjalan dengan tidak membosankan. Dengan terciptanya karya ini, anak-anak bisa belajar dengan cara bermain. Anak-anak akan mendapatkan edukasi Islam melalui sebuah permainan papan.
\end{abstract}

Kata kunci: permainan papan, huruf Hijaiyah, permainan Islami, permainan anak

\begin{abstract}
The world of children is identical with a games or playing. Children learn by playing or by playing a game. But as time goes on, many games have more negative effects on children. The creation of works with the title "Sibaaqun Educational Media Introduction to Hijaiyah Letters and Islamic Literature through the Board Game", has the purpose of conveying knowledge of Islam and introducing the Hijaiyah letters to children through board games. The creation of the work of this board game intends to reduce the negative impact that children receive when playing. By making a game by inserting education in it, and also how to make the game run is non-boring. With the creation of this work, children can learn by playing. Children will get Islamic education in a board game.
\end{abstract}

Keywords: board game, Hijaiyah letters, Islamic games, children's games 


\section{Pendahuluan}

\section{Latar Belakang}

Menurut Latif et al. (2013:77), "Para pakar sering mengatakan bahwa dunia anak adalah dunia bermain, dengan main anak belajar, artinya anak yang belajar adalah anak yang bermain, dan anak yang bermain adalah anak yang belajar."

Namun kenyataannya tidak semua game bersifat mendidik atau mengajar, dan tidak semua pelajaran bersifat bermain atau menyenangkan. Sedangkan anak-anak membutuhkan keduanya untuk perkembangan mereka yang masih berusia dini. Karena itulah mengapa tempat anak-anak mencari ilmu atau belajar disebut dengan taman kanak-kanak, taman pendidikan Alquran, dsb. Tim PrimaPena (t.t.:734) mengartikan taman sebagai tempat untuk bersenang-senang.

Penciptaan karya "Sibaaqun" ini akan membahas pembuatan board game sebagai media pembelajaran yang bersifat mendidik dan menyenangkan untuk anak-anak. Board game ini dibuat dengan tujuan utama mensyiarkan pengetahuan Islam. Umat islam memiliki kitab suci yaitu Alquran yang diturunkan dalam bahasa Arab. Dengan itu umat Islam harus bisa membaca dan memahami isi Alquran untuk mengamalkannya dalam kehidupan sehari-hari. Untuk itu diperlukan pendidikan untuk memahami Alquran. Langkah awal dalam mempelajari Alquran adalah dengan mengenal huruf-huruf Arab atau yang biasa disebut dengan huruf Hijaiyah.

Usia anak-anak adalah usia yang paling mudah untuk mempelajari bahasa, dan penyampaian materi kepada anak-anak berbeda dengan penyampaian kepada orang dewasa. Maka dari itu sebaiknya anak sudah mulai dikenalkan dengan huruf Hijaiyah sejak dini dengan metode yang menarik sesuai dengan kebutuhan mereka. Pengajaran huruf Hijaiyah pada anak di Indonesia sebenarnya sudah berlangsung lama dalam bentuk belajar mengaji Alquran yang sekarang berkembang pesat dengan bentuk TPA (Taman Pendidikan Alquran). Namun sifat pengajarannya masih dengan metode yang menurut beberapa anak membosankan. Pada kenyataannya, mereka hanya belajar pada saat di TPA, setelah pulang dari TPA mereka kembali bermain dengan permainan yang ada pada zaman modern ini. Untuk itu, harus ada penyesuaian media pengenalan huruf Hijaiyah untuk anak anak dengan situasi yang ada pada zaman modern ini. 
Dari paparan latar belakang di atas, maka penciptaan karya "Sibaaqun" ini akan menjelaskan tentang pembuatan board game "Sibaaqun" sebagai media pengenalan huruf Hijaiyah untuk anak anak.

\section{Rumusan Masalah}

Berdasarkan latar belakang di atas, dapat dirumuskan permasalahan yang akan diselesaikan sebagai berikut:

1. Penyampaian pengetahuan Agama Islam melalui media board game

2. Pengenalan huruf-huruf Hijaiyah dan nama-nama surat dalam Alquran melalui media board game "Sibaaqun"

\section{Tujuan}

Tujuan dari penciptaan karya board game "Sibaaqun" antara lain:

1. Menjadikan board game "Sibaaqun" sebagai media pembelajaran bagi ana-anak Muslim.

2. Mensyiarkan ilmu pengetahuan Islam melalui board game,

3. Mengenalkan huruf-huruf Hijaiyah dan nama-nama surat dalam Alquran

\section{Batasan Masalah}

Batasan masalah dari penciptaan karya board game "Sibaaqun" antara lain:

1. Hanya berisi ilmu pengetahuan Islam dan kitab suci Alquran.

2. Hanya terdapat empat masjid utama pada papan permainan, yaitu Masjid Istiqlal, Masjid Al Aqsha, Masjid Nabawi, dan Masjidil Haram.

\section{Target Audien}

Target audien penciptaan board game "Sibaaqun" ini adalah:
1. Usia
$: 5+$
2. Jenis kelamin : Laki-laki dan perempuan
3. Pendidikan : Berbagai latar pendidikan
4. Status sosial : Semua kalangan
5. Negara : Global

\section{Landasan Teori}




\section{Pengertian Game Edukasi}

Game berasal dari bahasa Ingris. Menurut Hariyono dan Idel (2005:215) game (geim) berarti permainan. Costikyan (2013:20) mendefinisikan bahwa game adalah sebentuk karya seni di mana peserta, yang disebut pemain, membuat keputusan untuk mengelola sumber daya yang dimilikinya melalui benda di dalam game demi mencapai tujuan.

Berdasarkan uraian di atas maka dapat disimpulkan bahwa Game ataupun permainan adalah sebuah aktifitas yang dilakukan satu atau lebih pemain dengan aturan tertentu sehingga ada yang menang dan kalah dengan tujuan bersenangsenang, mengisi waktu luang atau refreshing. Game dimainkan terutama untuk hiburan, kesenangan, tetapi dapat juga berfungsi sebagai sarana latihan, pendidikan dan simulasi. game dapat mengasah kecerdasan dan keterampilan otak dalam mengatasi konflik atau permasalahan buatan yang ada dalam permainan. Pemain dihadapkan dengan sistem dan konflik buatan. Konflik atau masalah dalam setiap game berbeda-beda. Konflik dalam setiap game menuntut pemain untuk menyelesaikannya dengan cepat dan tepat sehingga dapat meningkatkan konsentrasi dan melatih otak untuk memecahkan masalah dengan tepat dan cepat. Game juga dapat merugikan karena apabila terlalu sering bermain game maka pemain akan lupa waktu melakukan pekerjaan lainnya, sehingga membuat pekerjaan lain menjadi tertunda.

Kata edukasi berasal dari bahasa Inggris education. Menurut Hariyono dan Idel (2005:181) education (ejekeishen) berarti pendidikan. Prensky (2012: 90), mendefinisikan bahwa game edukasi adalah game yang didesain untuk belajar, tapi tetap bisa menawarkan bermain dan bersenang-senang. Game edukasi adalah gabungan dari konten edukasi, prinsip pembelajaran, dan game komputer.

Berdasarkan uraian di atas maka dapat disimpulkan game edukasi merupakan salah satu jenis game yang tidak hanya bersifat menghibur tetapi didalamnya mengandung pengetahuan yang disampaikan kepada penggunanya. Game edukasi dapat digunakan sebagai salah satu media pendidikan yang bisa digunakan sebagai media pembelajaran. Game jenis ini biasa digunakan untuk mengajak penggunanya belajar sambil bermain. Melalui proses belajar ini maka penggunanya dapat memperoleh ilmu pengetahuan, sehingga game edukasi merupakan terobosan baru 
yang digunakan dalam dunia pendidikan. Selain dikarenakan game jenis ini memadukan antara sisi belajar dan bermain, game jenis ini juga dapat digunakan untuk menarik perhatian anak-anak untuk belajar.

\section{Pengertian Pengenalan Huruf Hijaiyah}

Menurut Susanto (2011:86) "Pengertian mengenal huruf untuk pendidikan anak usia dini yaitu anak belajar mengenal huruf dan bunyinya dari konteksnya dari bahasa yang digunakan. Anak diarahkan untuk mengidentifikasi bentuk huruf dan bunyinya. Jadi anak belajar dari konsep menyeluruh menuju kekonsep khusus.”

Dalam hal ini konsep menyeluruh yang dikenalkan pada anak adalah hurufhuruf hijaiyah yang berjumlah 28 huruf, sementara konsep khusus yang dikenalkan adalah bentuk-bentuk huruf dan bunyinya. Huruf hijaiyah, secara arti huruf seperti yang kita kenal dalam bahasa Indonesia yang terdiri dari 26 huruf. Sedangkan dalam bahasa Arab terdapat 28 huruf yang kita kenal dengan huruf hijaiyah.

Berdasarkan uraian di atas, dapat disimpulkan bahwa kemampuan mengenal huruf hijaiyah adalah penguasaan mengenali huruf-huruf dan bunyi dari huruf hijaiyah yang berjumlah 28 huruf berdasarkan bentuk, bunyi dan konteksnya dari bahasa yang digunakan, dalam hal ini bahasa Alquran.

\section{Anak-anak dan Permainan}

Menurut Latif et al (2013:77) "Para pakar sering mengatakan bahwa dunia anak adalah dunia bermain, dengan main anak belajar, artinya anak yang belajar adalah anak yang bermain, dan anak yang bermain adalah anak yang belajar.” 
Soendari dan Wismiarti dalam Latif et al (2013:77) menjelaskan tentang bermain sebagai berikut.

"Anak bermain dengan mainan yang konkret (nyata). Dengan mainan tersebut anak akan belajar banyak hal seperti warna, ukuran, bentuk, besar kecil, berat ringan, kasar halus, selain itu anak juga akan belajar mengelompokkan benda, ciri ciri benda, dan sifat sifat benda. Kemapuan anak untuk belajar tersebut akan terus terbangun baik saat anak anak bermain maupun saat mereka beresberes setelah bermain"

Partai Kerja Brithis Educational Research Association Early Years Special Interest Group (BERA EYSIG) dalam Nutbrown dan Clough (2015:252) mengulas penelitian pedagogi usia dini, kurikulum dan peran orangtua. Tinjauan tersebut mencatat bahwa:

Beberapa studi penting telah memberi bukti berdasarkan kualitas permainan, manfaat manfaat pendidikan, dan pedagogi permainan, dalam konteks tatanan prasekolah dan sekolah (Tizard et al. 1975, Sylva et al. 1980, Wood et al. 1980, Meadows dan Cashdan, 1988, Hutt et al.1989, Bennett dan Kell, 1989, Cleave dan Brown, 1991, Bennett et al. 1997). Hampir semua studi ini tidak berfokus secara spesifik mengenai permainan, tetapi pada kurikulum dan proses pedagogis yang lebih luas, dimana permainan merupakan sebuah bagian tak terpisahkan. Penemuan mereka penting mengenai kualitas permainan; dislokasi antara retorika dan realita permainan; sejauh mana permainan dan pembelajaran dikaitkan; peran orang dewasa dalam permainan anak anak, dan bagaimana permainan digunakan menuju hasil pendidikan. Gambar konsisten yang muncul dari penelitian penelitian ini adalah bahwa permainan pada praktiknya dibatasi oleh frekuensi, durasi dan kualitas, dengan guru guru dan orang dewasa lainnya yang terlalu sering menggunakan pendekatan 'melihat dan menunggu' yang reaktif. (BERA EYSIG, 2003: 14)

Dengan pemahaman-pemahaman di atas dapat disimpulkan bahwa bermain pada saat usia dini sangat penting bagi perkembangan anak. Karena dengan bermain, secara tidak langsung anak juga sedang belajar dengan cara yang menyenangkan. Maka pada saat usia dini, permainan dan pembelajaran akan saling mengaitkan dalam perkembangan anak. 


\section{Prinsip Pendidikan Anak}

Montolalu dalam Latif et al (2013:80) mengatakan "Pada hakikatnya anak anak selalu termotivasi untuk bermain. Artinya, bermain secara alamiah memberi kepuasan pada anak, melalui bermain bersama dalam kelompok atau sendiri tanpa orang lain, anak mengalami kesenangan yang lalu memberikan kepuasan baginya”

\section{Game Sebagai Media Pembelajaran Huruf Hijaiyah}

Dari uraian-uraian di atas, telah dijelaskan mengenai game edukasi, pengenalan huruf hijaiyah, kaitan permainan dengan pembelajaran, dan prinsip pendidikan usia dini. Melalui penjelasan penjelasan tesebut, bisa diketahui bahwa permainan dan pembelajaran sangat penting bagi perkembangan anak usia dini. Mereka membutuhkan keduanya tanpa harus meninggalkan salah satunya. Karena hakikatnya, anak anak memang identik dengan bermain. Dan di sisi lain, anak anak juga membutuhkan pendidikan untuk masa depannya.

Pada zaman modern ini, permainan mengalami perkembangan yang sangat pesat terutama pada teknologi. Jika dulu anak anak bermain dengan permainan tradisional seperti kelereng, petak umpet, gobak sodor, congklak, dll, kini permainan permainan itu sudah bisa dimainkan dengan teknologi handphone.

Untuk menyesuaikan dengan perkembangan zaman, game memiliki peran penting dalam pendidikan anak usia dini. Karena saat ini sudah banyak anak usia dini yang sudah memiki handphone untuk bermain. Game pada handphone sangat berpeluang untuk memberikan dampak negatif pada anak usia dini. Tapi hal itu bisa dihindari dengan diciptakannya game-game edukasi yang mengajak anak-anak untuk bermain sambil belajar. Maka dari itu, perlu ada inovasi dalam pembelajaran pengenalan huruf hijaiyah. Agar anak-anak muslim tidak terpengaruh kepada game-game yang membuat lalai mereka dari menuntut ilmu Alquran. Dengan adanya game-game edukasi islami yang mengajarkan huruf hijaiyah sambil bermain, anak-anak pada zaman ini akan lebih tertarik untuk belajar mengenal huruf hijaiyah, karena mereka lebih merasa terhibur dengan adanya permainan, juga tidak meninggalkan kewajibannya untuk belajar Alquran.

\section{Tinjauan Karya}


Penciptaan board game "Sibaaqun" ini mengambil referensi dari beberapa karya lainnya dari segi konsep gameplay, visual, dan komponen. Ada pun karya yang menjadi acuan adalah:

\section{Mekanika Permainan (Gameplay)}

Mekanika permainan adalah istilah bagaimana sebuah permainan itu berjalan dan bisa dimainkan, di dalamnya terdapat pertaturan bermain, cara bermain, bagaimana kondisi ketika menang, kondisi ketika kalah, dan bagaimana sebuah permainan itu selesai.

Berikut adalah karya-karya yang menjadi refrensi dalam aspek mekanika permainan (gameplay).

\section{a. Cookie Box}

Pada board game "Cookie Box" ini yang menjadi ide dan atau acuan adalah konsep gameplay, yaitu dengan meyusun gambar-gambar sesuai dengan misi yang didapat.

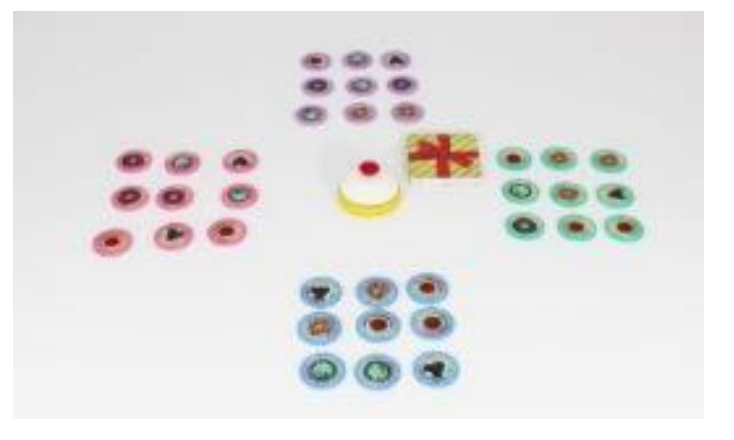

Gambar 1. Board Game "Cookie Box"

\section{b. Monopoly \& Ular Tangga}

Pada board game "Monopoly" ini yang diambil adalah konsep gameplay dari kartu-kartu untuk membuat misi dan tantangan. Cotohnya adalah kartu maju beberapa langkah, mundur beberapa langkah, kembali ke start, dan lain sebagainya. Kartu-kartu tantangan ini berperan sebagai penambah atau pemanis permainan "Sibaaqun". Sedangkan pada board game "Ular Tangga" ini yang 
menjadi ide dan atau acuan adalah konsep gameplay race, yaitu balapan antara pemain.

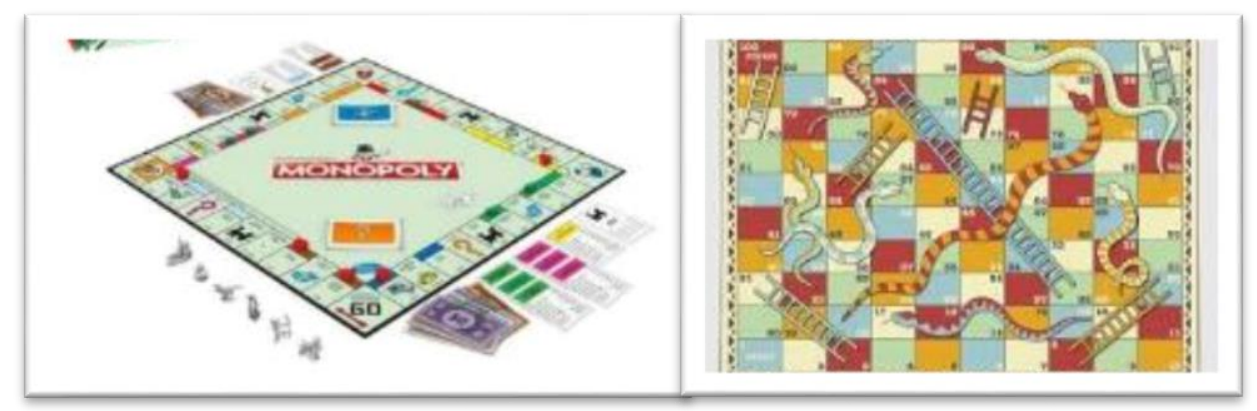

Gambar 2. Board Game "Monopoly" dan "Ular Tangga"

\section{Papan Utama (Main Board)}

Main Board adalah sebuah papan yang menjadi arena permainan dalam sebuah board game. Berikiut adalah beberapa karya yang menjadi referensi dalam aspek main board.

\section{a. Tri Fold Game Board}

Main board yang akan digunakan pada board game "Sibaaqun" adalah main board dengan konsep Tri Fold, yaitu board bisa dilipat menjadi empat. Konsep ini digunakan supaya ukuran board bisa menjadi lebih kecil ketika dimasukkan ke dalam box packaging.

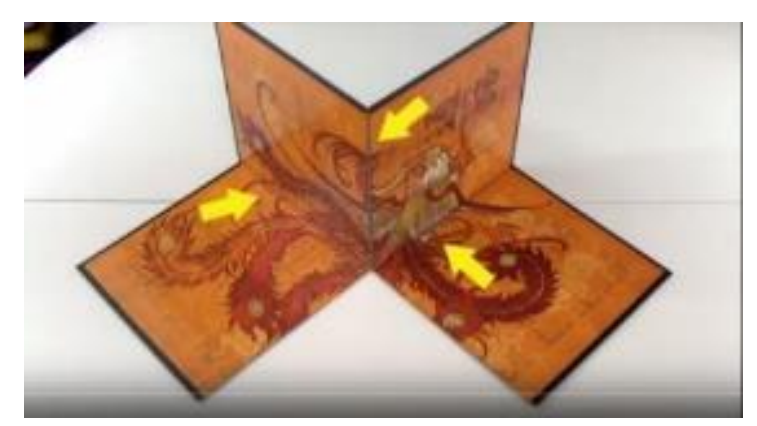

Gambar 3. Tri Fold Game Board

\section{b. Shopkins}

Pada boardgame Shopkins, yang dijadikan sebagai referensi adalah desain visual pada papannya, yaitu berbentuk lingkaran yang menyombolkan bahwa ketika bermain, pemain akan mengelilingi papan layaknya mengelilingi dunia. 


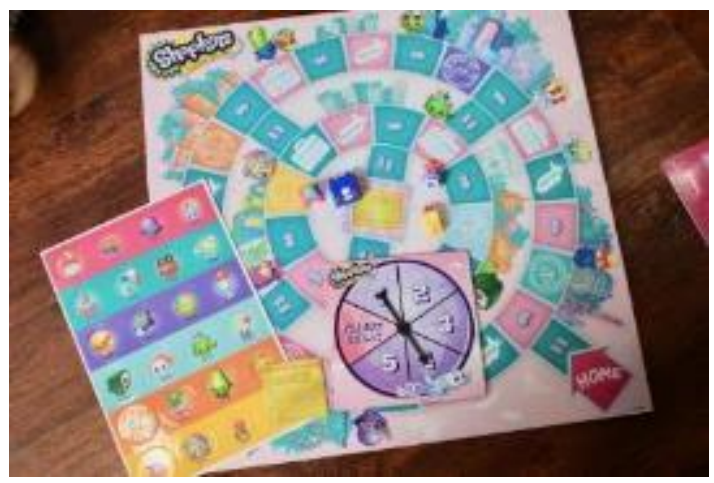

Gambar 4. Board Game "Shopkins"

\section{Card Design}

Desain untuk ilustrasi kartu untuk permainan papan "Sibaaqun" mengacu kepada gambar berikut.
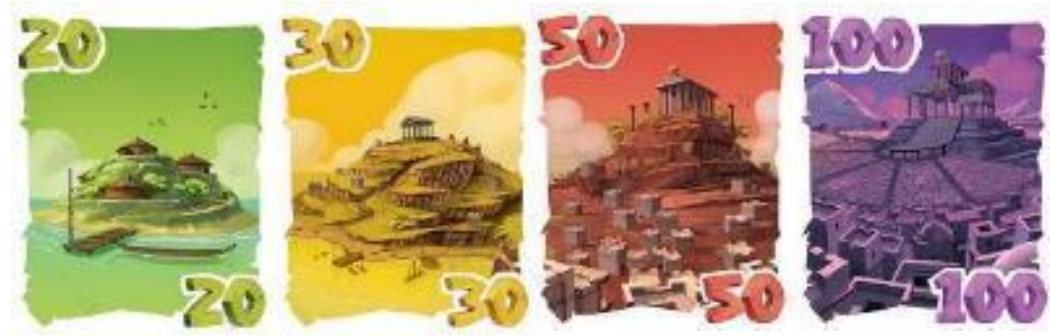

Gambar 5. Referensi desain kartu

Desain tersebut tidak diketahui dari game apa, gambar tersebut ditemukan di website pinterest.com. Desain dari kartu tersebut menjadi referensi karna tema yang mirip dengan konsep papan permainan "Sibaaqun", yaitu memiliki empat warna yang berbeda untuk identitas setiap pemain. 


\section{Kemasan}

Kemasan dari permainan papan Komplimentas menjadi refrensi dan atau ide untuk pembuatan kemasan board game "Sibaaqun". Keunggulan dari kemasan ini adalah komponen-komponen board game tertata dengan rapih dan tidak ada ruang yang

tersisa/kosong.

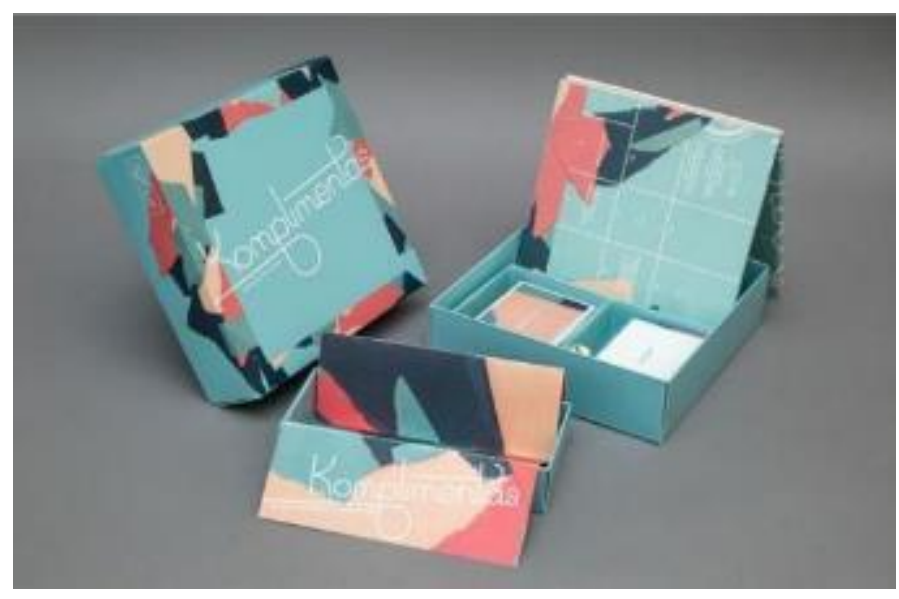

Gambar 6. Kemasan "Komplimentas"

\section{Pembahasan}

Permainan papan "Sibaaqun" adalah sebuah karya board game yang dibuat dengan desain, mekanika, visual yang sedemikian rupa dengan berdasarkan kepada rumusan masalah yang di dapat, yaitu pengenalan huruf-huruf Hijaiyah dan nama-nama surat dalam Alquran. Boardgame "Sibaaqun" dibuat dengan tujuan untuk menjadikan boardgame "Sibaaqun" sebagai media pembelajaran bagi anal-anak Muslim, mensyiarkan ilmu pengetahuan Islam melalui board game, dan untuk mengenalkan huruf-huruf Hijaiyah dan nama-nama surat dalam Alquran. Berdasarkan rumusan masalah dan tujuan dari penciptaan karya board game "Sibaaqun ini, maka karya memiliki target audien yang ditujukan kepada anak-anak usia 5 tahun keatas, laki-laki dan perempuan dengan berbagai latar pendidikan.

Untuk menciptakan karya yang didasari dengan rumusan masalah dan tujuan supaya sesuai dengan target yang dituju, maka diperlukan eksplorasi referensi untuk membuat sebuah ide karya menjadi karya nyata dan mencapai tujuan dari penciptaan 
karya tersebut untuk menyelesaikan sebuah rumusan masalah yang didapat. Berikut ini akan dijelaskan perbandingan karya board game "Sibaaqun" dengan karya-karya yang menjadi referensi, perbandingan akan dibahas berdasarkan aspek-aspek tertentu, berikut adalah perbandingan karya.

\section{A. Mekanika Permainan (Gameplay)}

Mekanika permainan adalah istilah bagaimana sebuah permainan itu berjalan dan bisa dimainkan, di dalamnya terdapat pertaturan bermain, cara bermain, bagaimana kondisi ketika menang, kondisi ketika kalah, dan bagaimana sebuah permainan itu selesai.

Berikut adalah perbandingan karya board game Sibaaqun dengan karya-karya yang menjadi refrensi dalam aspek mekanika permainan (gameplay).

\section{Cookie Box}

Pada board game "Cookie Box" ini yang menjadi ide dan atau acuan adalah konsep mekanika permainannya (gameplay), yaitu dengan meyusun gambar-gambar sesuai dengan misi yang didapat. Pada board game "Sibaaqun" ini yang dijadikan token-tokennya adalah macam-macam huruf Hijaiyah, yang nantinya akan disusun menjadi sebuah nama surat-surat dalam Alquran. Gambar berikut menjelaskan bagaimana penyelesaian sebuah misi dalam permainan "Sibaaqun", yaitu dengan menyusun huruf-huruf Hijaiyah untuk menyesuaikannya dengan misi yang didapat melalui kartu misi.

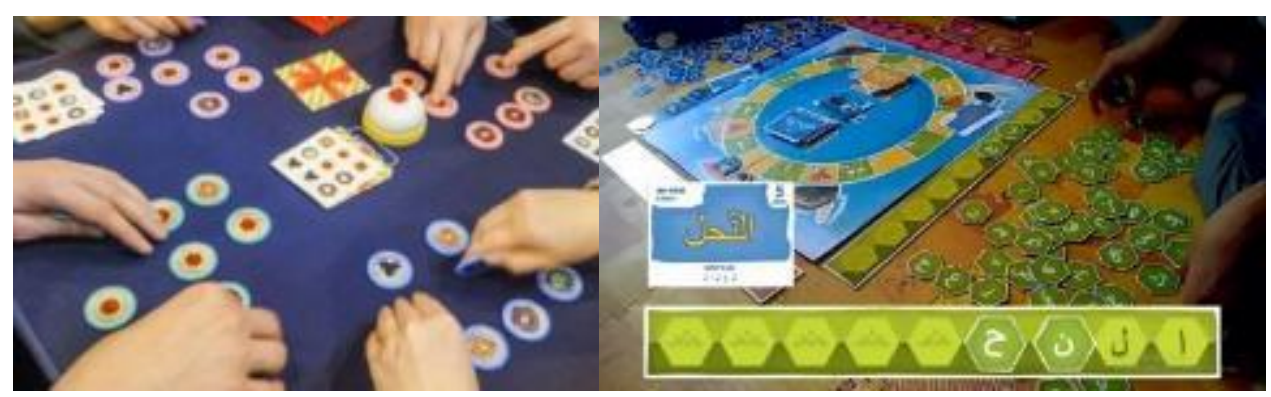

Gambar 7. Mekanika Board Game "Cookie Box" daan "Sibaaqun" 


\section{Ular Tangga}

Pada board game "Ular Tangga" ini yang menjadi ide dan atau acuan adalah konsep gameplay race, yaitu balapan antara pemain. Pada board game "Sibaaqun, permainan juga berjalan dengan konsep balapan (race) dengan dimulai dari petak start, kemudian finish pada petak Masjidil Haram.

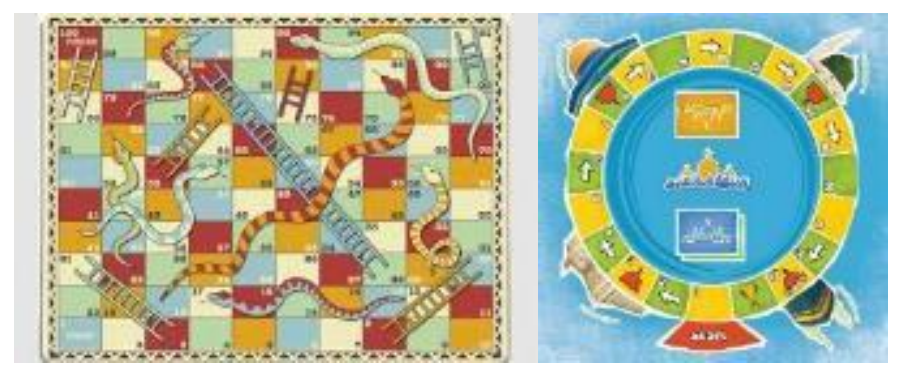

Gambar 8. Map Board Game "Ular Tangga" dan "Sibaaqun"

\section{Monopoly}

Pada board game "Monopoly" ini yang menjadi ide dan atau acuan adalah konsep mekanika dari kartu-kartu untuk membuat misi dan tantangan. Cotohnya adalah kartu maju beberapa langkah, mundur beberapa langkah, kembali ke start, dan lain sebagainya. Kartu-kartu tantangan ini berperan sebagai penambah atau pemanis dalam permainan "Sibaaqun".

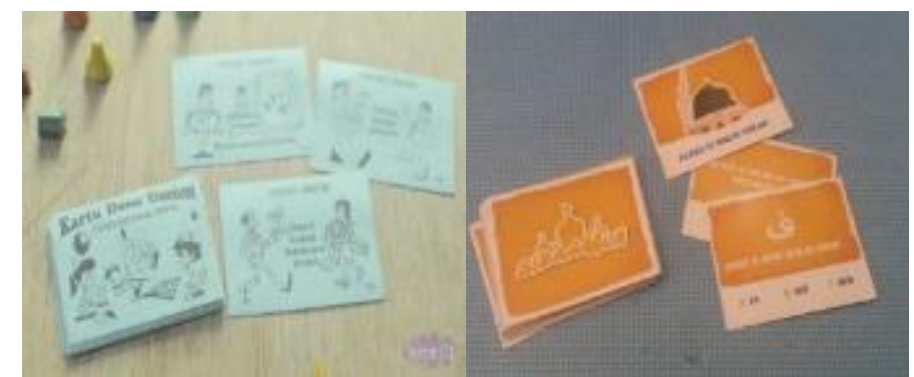

Gambar 9. Kartu dana umum Board Game "Monopoly" \& Kartu Tantangan "Sibaaqun"

Selain kartu-kartu yang berisi berupa perintah, dalam permainan "Sibaaqun" juga terdapat kartu-kartu pertanyaan yang isinya tentang edukasi Islam. Melalui kartu-kartu ini pemain akan menambah pengetahuannya dengan cara yang menyenangkan.

\section{B. Papan Utama (Main Board)}


Main Board adalah sebuah papan yang menjadi arena permainan dalam sebuah board game. Berikiut adalah beberapa karya yang menjadi referensi dalam aspek main board.

\section{Tri Fold Game Board}

Main board yang akan digunakan pada board game "Sibaaqun" adalah main board dengan konsep Tri Fold, yaitu board bisa dilipat menjadi empat. Konsep ini digunakan supaya ukuran board bisa menjadi lebih kecil ketika dimasukkan ke dalam box packaging. Berikut adalah main board pada board game "Sibaaqun" dengan menggunakan konsep tri fold game board.

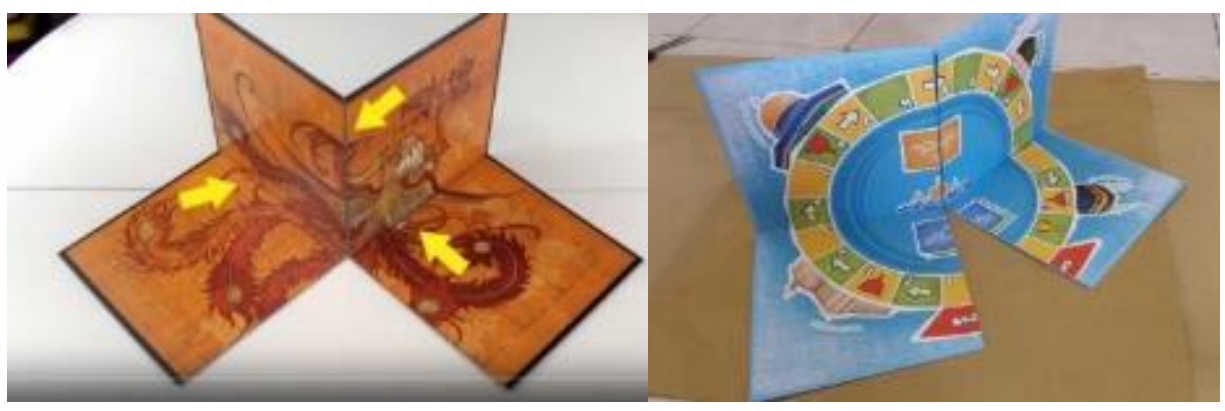

Gambar 10. Tri Fold Game Board

\section{Shopkins}

Pada board game Shopkins, yang dijadikan sebagai referensi adalah desain visual pada papannya, yaitu berbentuk lingkaran yang menyombolkan bahwa ketika bermain, pemain akan mengelilingi papan layaknya mengelilingi
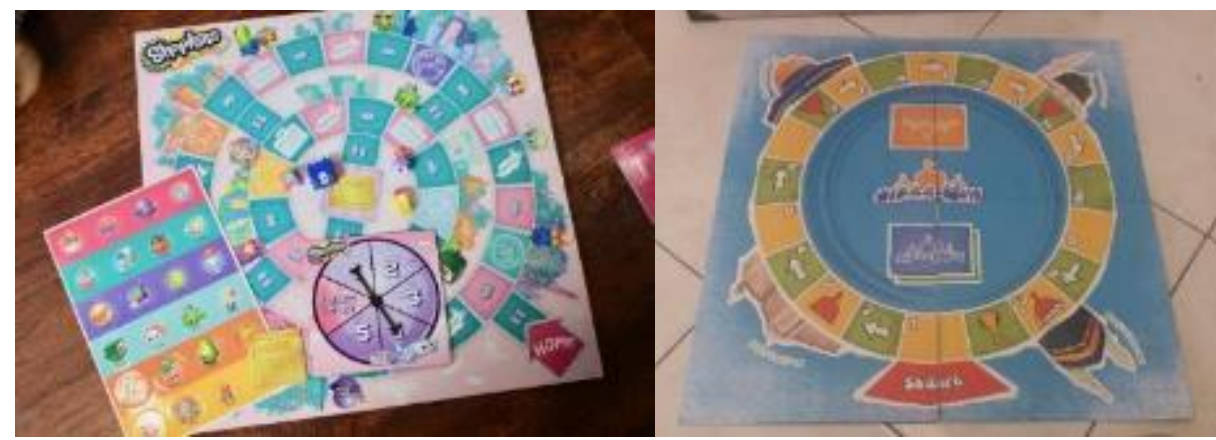

dunia.

Gambar 11. Board Game "Shopkins" dan "Sibaaqun"

\section{Desain Kartu}


Desain untuk ilustrasi kartu untuk permainan papan "Sibaaqun" mengacu kepada gambar berikut.

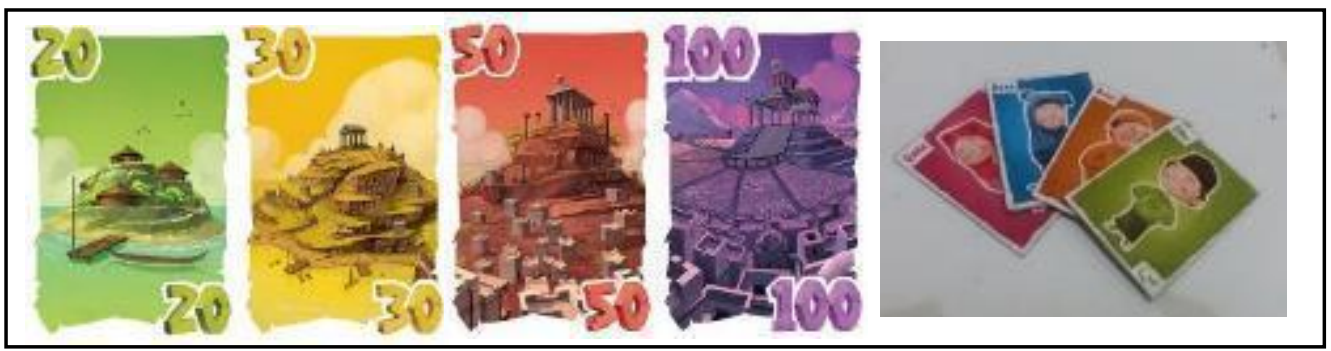

Gambar 12. Referensi Desain Kartu dan Kartu Karakter "Sibaaqun"

Desain tersebut tidak diketahui dari game apa, gambar tersebut ditemukan di website pinterest.com. Desain dari kartu tersebut menjadi referensi karna tema yang mirip dengan konsep papan permainan "Sibaaqun", yaitu memiliki empat warna yang berbeda untuk identitas setiap pemain.

\section{Kemasan}

Kemasan dari permainan papan Komplimentas menjadi refrensi dan atau ide untuk pembuatan kemasan board game "Sibaaqun". Kemasan ini menjadi referensi karna komponen yang berada dalam box mirip dengan komponen-komponen yang akan dibuat pada papan permainan "Sibaaqun", yaitu terdapat papan utama (main board) dan kartu-kartunyya.

Keunggulan dari kemasan ini adalah komponen-komponen board game tertata dengan rapih dan tidak ada ruang yang tersisa/kosong.

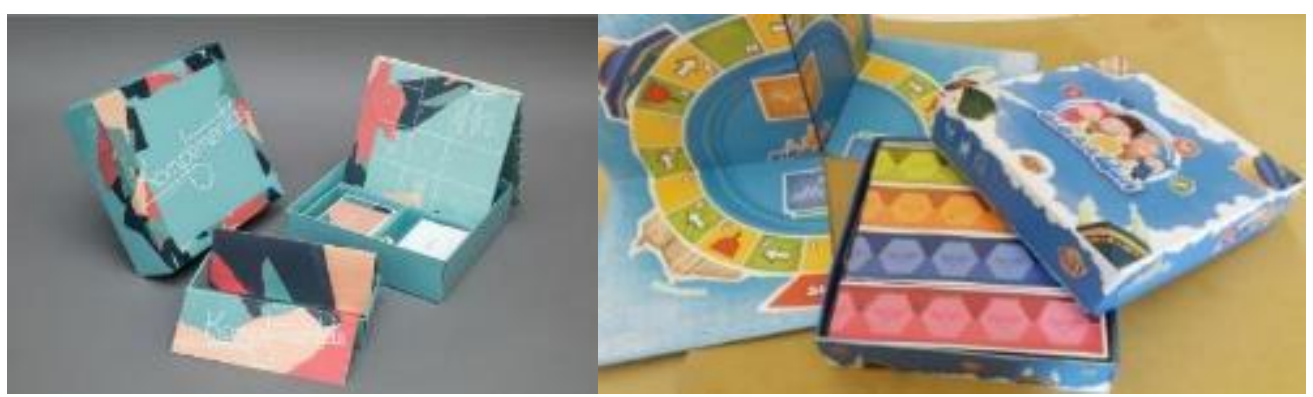

Gambar 13. Kemasan "Komplimentas" dan "Sibaaqun"

\section{Rancangan Cara Bermain}

a. Jumlah Pemain dan Target Umur Pemain 
Permainan ini dimainkan oleh dua sampai empat pemain. Dan dimainkan oleh anak-anak umur lima tahun keatas, bisa juga orang tua dengan anak, dan atau guru dengan anak murid.

\section{b. Kondisi Menang}

Kondisi menang adalah ketika poin berjumlah paling banyak.

\section{c. Kondisi Kalah}

Kondisi kalah ketika jumlah poin paling sedikit.

\section{d. Kondisi Seri}

Kondisi seri, jika pemain yang bernilai seri maka akan balapan lagi satu kali menuju finish. Yang sampai finish lebih dulu adalah pemenangnya.

e. Persiapan bermain:

1) Letakkan Main Board di tengah-tengah antara pemain

2) Masing-masing pemain memilih pion karakter dan meletakkannya di start.

3) Masing-masing pemain mendapatkan player board / hijaiyah area, dan meletakkannya di hadapan pemain tersebut.

4) Masing-pemain mendapatkan 34 keping token huruf.

5) Masing-masing pemain mendapatkan kartu pemain

6) (Permainan level sulit) kocok kartu misi (biru), letakkan di tempat yang disediakan dengan keadaan tertutup.

7) (Permainan level mudah) kocok kartu misi (Hijau), letakkan di tempat yang disediakan dengan keadaan tertutup.

8) Kocok kartu tantangan, letakkan di tempat yang disediakan dengan keadaan tertutup 


\section{f. Cara bermain}

1) Kocok kartu misi sulit atau kartu misi mudah (pilih salah satu), bagikan ke player masing-masing satu kartu dengan keadaan tertutup.

2) Pemain membuka kartu misi secara bersamaan. Susun huruf hijaiyah berdasarkan kartu misi yang telah dibuka

3) Semua pemain memulai menyusun huruf hijaiyah sesuai dengan masingmasing kartu misi yang telah dibuka.

4) Ketika pemain selesai menyusun huruf, lempar kartu pemain ke tempat yang telah disediakan di main board

5) Maka, yang pertama menyelesaikan susunan huruf akan melempar paling pertama. Selanjutnya pemain yang akan menyelesaikan kedua akan melempar kartu pemain nya dan meletakkannya di atas kartu pemain pemain pertama. Dalam arti lain pemain yang terakhir menyelesaikan susunan huruf maka kartu pemain nya berada di paling atas.

6) Setelah kartu pemain dari setiap pemain sudah tertumpuk. Maka kartu yang berada di paling bawah akan memindahkan karakternya dengan maju 4 langkah, kemudian kartu pemain diatasnya memindahkan karakternya maju 3 langkah, kemudian kartu pemain diatasnya memindahkan karakter maju 2 langkah, dan kartu pemain yang berada di paling atas memindahkan karakternya dengan maju 1 langkah

7) Setelah semua karakter telah bergerak. Maka semua pemain akan mengambil satu kartu misterius. Urutan mengambil kartu misterius diawali pemain yang tadi meletakkan kartu pemain paling bawah, dan selanjutnya bergilir sesuai posisi masing2 kartu PEMAIN. 9. kartu misterius berisi macam-macam hadiah, cobaan, atau kuis, diantaranya:

a) Maju 3 langkah (maka pemain harus maju 3 langkah)

b) Mundur 3 langkah (maka pemain harus mundur 3 langkah)

c) Menuju ke petak 20

d) Menuju ke Masjid Al Aqsha

e) Kembali ke start

f) Kartu Perlindungan

g) Shalat Isya dilakukan pada waktu: A. Pagi B. Malam (pemain bisa 
menjawab atau melempar pertanyaan ini ke pemain lain. jika jawabannya benar, pemain maju 1 langkah. Jika salah, pemain mundur 1 langkah)

Begitu selanjutnya, semua pemain akan mendapatkan kembali kartu misi secara acak, dan menyusun huruf-hurufnya kemudian mengambil kartu misterius dan menjalankan aksi-aksinya. sampai semua pemain sampai ke finish (Masjidil Haram) Yang paling pertama sampai Masjid Istiqlal akan mendapatkan kartu hewan Unta yang bernilai 30. yang kedua akan mendapatkan kartu hewan Sapi yang bernilai 25. yang ketiga akan mendapatkan kartu hewan Kambing yang bernilai 15 dan yang paling terakhir akan mendapatkan kartu hewan Ayam yang bernilai 5.

g. Peraturan bermain:

1) Pemain tidak boleh berkata kasar selama permainan berlangsung, jika pemain berkata kasar, maka diharuskan segera beristighfar mengucap "astaghfirullah" dan pemain diharuskan mundur sebanyak tiga langkah (makna: meminta ampun kepada Allah ketika bersalah)

2) Tidak boleh bermain ketika waktu shalat

3) Permainan akan dimainkan sebanyak 3 putaran, artinya 3 kali finish

4) Pemain harus saling mengucapkan salam ketika bertemu dalam satu petak. Yang baru datang mengucap "assalamualaikum" dan yang berada di petak tersebut menjawab "waalaikumussalam" (makna: saling mendoakan ketika bertemu saudara)

5) Ketika permainan sudah berjalan selama 3 putaran. maka jumlahkan semua poin kartu hewan qurban yang didapat masing-masing pemain.

6) Poin berjumlah paling banyak adalah pemenangnya.

7) Jika seri, maka yang pemain yang bernilai seri tersebut akan balapan lagi satu kali menuju masjid, dan yang sampai duluan maka dia adalah pemenangnya. 


\section{Penutup}

\section{Kesimpulan}

Kesimpulan yang didapatkan dari seluruh proses pembuatan karya "Sibaaqun" Edukasi Pengenalan Huruf Hijaiyah melalui Papan Permainan

1. Penciptaan board game "Sibaaqun" sebagai media pengenalan huruf-huruf Hijaiyah dan nama-nama surat dalam Alquran.

2. Penciptaan board game "Sibaaqun" sebagai bentuk edukasi Islam melalui papan permainan.

3. Penciptaan board game "Sibaaqun" dengan menggunakan konsep tri fold game board pada media papan permainan.

4. Penciptaan board game "Sibaaqun" sebagai media pembelajaran untuk anank-anak muslim dengan melalui permainan papan.

\section{Saran}

Seluruh tahapan praproduksi, produksi dan pascaproduksi telah selesai, beberapa saran yang didapat dari board game tersebut antara lain: Menyebarluaskan karya board game Sibaaqun kepada lembaga-lembaga pendidikan, terutama pendidikan Alquran supaya dirasakan manfaatnya oleh target yang dituju.

1. Meskipun bermain dan belajar sangat penting untuk perkembangan anak, bukan berarti anak dibebaskan untuk selalu bermain atau dipaksa untuk selalu belajar. Keduanya harus seimbang agar perkembangan anak berproses dengan baik.

2. Disarankan untuk tidak sepenuhnya menjadikan game sebagai pendidikan Alquran untuk anak-anak muslim. Karena sebaik-baiknya belajar adalah dengan berguru langsung kepada yang memahami atau yang biasa disebut dengan metode talaqqi. Namun mengarahkan anak untuk bermain game edukasi islami seperti pengenalan huruf hijaiyah sangat dianjurkan, karena ini adalah salah satu upaya untuk menghindari dampak negatif terhadap teknologi zaman sekarang.

\section{Daftar Pustaka}

Costikyan, Greg. 2013. Uncertainly In Games. The MIT Press, Cambridge 
Hariyono, Rudy, \& Idel, Antoni. 2005. Kamus Lengkap Inggris-Indonesia dan Indonesia-Inggris Plus Idiom. Gitamedia Press

Latif, Mukhtar, et al. 2013. Orientasi Baru Pendidikan Anak Usia Dini: Teori dan Aplikasi. Jakarta: Kencana Prenada Media Group

Nutbrown, Catchy \& Clough, Peter. 2014. Early Childood Education, History, Philosophy, and Experience, Edisi ke-2. Pramono, Adhya Utama Larasati. 2015. Yogyakarta: Pustaka Belajar

Prensky, Mark. 2012. From Digital Natives to Digital Wisdom. New York.

PrimaPena, Tim. Tanpa tahun. Kamus Besar Bahasa Indonesia. Gitamedia

Susanto, Ahmad. 2011. Perkembangan Anak Usia Dini. Jakarta: Kencana Prenada Media Group 